\title{
The Emerging Role of Disturbed CoQ Metabolism in Nonalcoholic Fatty Liver Disease Development and Progression
}

\author{
Kathleen M. Botham ${ }^{1}$, Mariarosaria Napolitano ${ }^{2}$ and Elena Bravo ${ }^{2, *}$ \\ Received: 29 September 2015; Accepted: 12 November 2015; Published: 1 December 2015 \\ 1 Department of Comparative Biomedical Sciences, The Royal Veterinary College, Royal College St., \\ London NW1-0TU, UK; kbotham@rvc.ac.uk \\ 2 Department of Haematology, Oncology and Molecular Medicine, Istituto Superiore di Sanità, Rome 00161, \\ Italy; mariarosaria.napolitano@iss.it \\ * Correspondence: elena.bravo@iss.it; Tel.: +39-6-49903061; Fax: +39-6-49903050
}

\begin{abstract}
Although non-alcoholic fatty liver disease (NAFLD), characterised by the accumulation of triacylglycerol in the liver, is the most common liver disorder, the causes of its development and progression to the more serious non-alcoholic steatohepatitis (NASH) remain incompletely understood. Oxidative stress has been implicated as a key factor in both these processes, and mitochondrial dysfunction and inflammation are also believed to play a part. Coenzyme Q (CoQ) is a powerful antioxidant found in all cell membranes which has an essential role in mitochondrial respiration and also has anti-inflammatory properties. NAFLD has been shown to be associated with disturbances in plasma and liver CoQ concentrations, but the relationship between these changes and disease development and progression is not yet clear. Dietary supplementation with CoQ has been found to be hepatoprotective and to reduce oxidative stress and inflammation as well as improving mitochondrial dysfunction, suggesting that it may be beneficial in NAFLD. However, studies using animal models or patients with NAFLD have given inconclusive results. Overall, evidence is now emerging to indicate that disturbances in CoQ metabolism are involved in NAFLD development and progression to NASH, and this highlights the need for further studies with human subjects to fully clarify its role.
\end{abstract}

Keywords: non-alcoholic fatty liver disease; non-alcoholic steatohepatitis; Coenzyme Q; antioxidant; oxidative stress; inflammation; steatosis

\section{Introduction}

Non-alcoholic fatty liver disease (NAFLD), a condition in which triacylglycerol (TAG) accumulates in the liver, is the most common liver disorder worldwide [1,2]. Its occurrence in the general population has been estimated to be $20 \%-30 \%$, but in increasingly prevalent metabolic disorders, including obesity, diabetes type 2 and the metabolic syndrome, this rises to $70 \%-90 \%$. NAFLD itself is considered to be relatively benign, but in some cases its progression leads to liver conditions such as non-alcoholic steatohepatitis (NASH), fibrosis, cirrhosis and carcinoma which are more serious and may be life-threatening [1,2]. A better understanding of the causes of the development and progression of the disease, therefore, is now of great importance from a public health perspective [1,2].

NAFLD is known to be a multifactorial disease, but the reasons why progression occurs in some cases but not others are not yet well defined [3,4]. Recent work, however, has indicated that oxidative stress resulting from both insulin resistance and hepatic steatosis is likely to be a major causal factor in the development of NAFLD, and may also play an important part in its progression 
to more serious conditions such as NASH [4-7]. Coenzyme Q (CoQ) (also called ubiquinone) is an important cellular antioxidant found in all membranes [8-10]. Supplementation of the diet with CoQ has been found to influence plasma antioxidant and inflammatory markers in healthy men [11] and in patients with coronary artery disease [12,13], and animal studies have demonstrated effects on liver oxidative stress and lipid metabolism [14-16]. Furthermore, there is clear evidence to indicate that NAFLD is associated with perturbation of plasma and hepatic CoQ levels [17-19], and recent studies have demonstrated that CoQ metabolism is altered in an animal model of the disease [20]. Thus, there is growing evidence to suggest that disturbances in CoQ metabolism may play a part in the development and progression of NAFLD.

\section{CoQ Function and Metabolism}

$\mathrm{CoQ}$ is a lipophilic molecule consisting of a benzoquinone ring and a polyisoprenoid side chain (Figure 1). The side chain varies in length from species to species, and for the purposes of this review it is important to note that in humans it contains 10 isoprene units $\left(\mathrm{CoQ}_{10}\right)$, while in rats and mice, the most commonly used animal models for NAFLD, it has $9\left(\mathrm{CoQ}_{9}\right)$ [21]. It is found in all cell membranes and is unique among naturally occurring lipophilic antioxidant in that it is synthesised de novo in animals [8-10]. The best known function of CoQ is in mitochondrial respiration. The side chain serves to keep the molecule anchored in the inner mitochondrial membrane, and the quinone ring, which is easily and reversibly reduced to the quinol form (Figure 1), enables it to carry out its function of transferring electrons from complexes I and II to complex III in the respiratory chain, ultimately resulting in the reduction of oxygen to water and the generation of ATP $[10,21]$. In addition to this essential role in energy generation, CoQ is now thought to have a number of other functions in the body, including regulation of mitochondrial functions such as membrane transition pore permeability and the activation of uncoupling proteins, counteraction of endothelial dysfunction by stimulating nitric oxide production, and, of particular interest in relation to NAFLD, acting as an anti-inflammatory agent and a lipophilic antioxidant protecting lipids, protein and DNA from oxidation $[8,22,23]$.

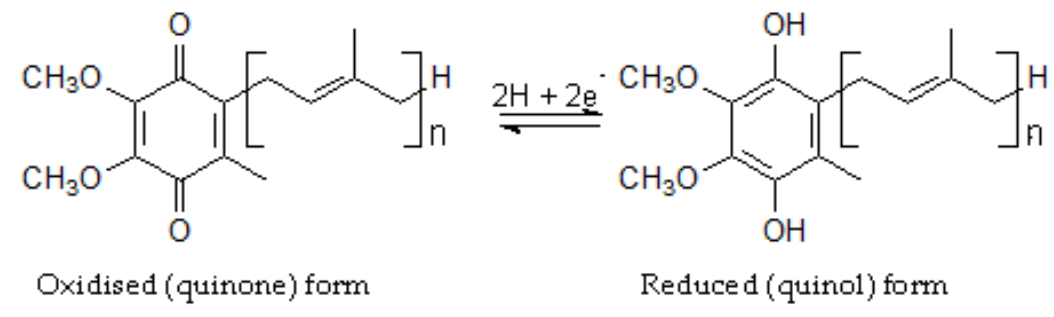

Figure 1. The oxidised and reduced forms of Coenzyme $\mathrm{Q}(\mathrm{CoQ})$. The oxidised and reduced forms of $\mathrm{CoQ}$ are interconverted by the addition or loss of $2 \mathrm{H}+2 \mathrm{e}^{-} \cdot n=10$ in humans and 9 in rats and mice.

CoQ is synthesised by a complex pathway involving the conjugation of the polyprenyl side chain with para hydroxybenzoic acid (PABA) the precursor of the benzoquinone moiety, followed by a series of modifications to the ring which result in the final structure [21-23]. At least nine enzymes are believed to participate in the pathway, and the steps specific to CoQ take place inside mitochondria. Isoprene monomers are synthesised via the mevalonate pathway in the cytosol, and are then condensed by the complex Pdss1/Pdss2, thus this enzyme determines the number of isoprene units in the CoQ side chain [21-23]. Deficiency of CoQ is known to occur in humans and leads to various mitochondrial disorders which have diverse clinical manifestations, including encephalomyopathy, ataxia, myopathy and a nephrotic syndrome $[21,24,25]$. The disorders may be primary or secondary. Primary disorders caused by defects in the biosynthetic pathway are rare, but mutations in a number of the genes in the pathway, including Pdss1 and Pdss2, have been identified (see reference [21] for a comprehensive list). Secondary deficiencies may result from defects in proteins unrelated to CoQ 
biosynthesis such as aprataxin, which has a role in double stranded DNA repair, mitochondrial DNA depletion, or the use of statins to combat hypercholesterolemia [21,24,25]. Although endogenous synthesis is normally able to meet the body's need for CoQ, there are circumstances in which deficiencies not caused by genetic defects may occur. Statins, drugs widely used to lower blood cholesterol, can depress CoQ synthesis as they inhibit 3-hydroxy-3-methylglutaryl Coenzyme A reductase (HMG-CoA reductase), the rate-limiting enzyme in the pathway of cholesterol synthesis which includes the formation of the isoprenoid units required to produce CoQ [21,26]. In addition, CoQ levels may be pathologically changed in conditions associated with oxidative stress and in aging [27]. Current evidence suggest that dietary CoQ supplementation may be beneficial in many of these cases, but it is not yet used routinely in clinical practice $[24,28]$.

\section{Antioxidant and Anti-Inflammatory Functions of CoQ}

CoQ is biosynthesised in all tissues of the body, and, although it was initially believed to be confined to the inner mitochondrial membrane because of its function in the respiratory chain [29], it is now know to be present in all cell membranes [8,23]. Because of its widespread distribution and membrane location, $\mathrm{COQ}$ is the most highly efficient of the naturally occurring lipophilic antioxidants [8]. In the membrane CoQ is in close proximity to lipid and protein molecules in need of protection from locally produced peroxy radicals. Much of the CoQ found in the body is in the antioxidant quinol form (Figure 1), although this varies between tissues [8]. The quinol prevents lipid peroxidation by inhibiting the initial formation and propagation of lipid peroxy radicals (LOO), and in the process it is oxidised to the quinone (Figure 1) and $\mathrm{H}_{2} \mathrm{O}_{2}$ is produced. In addition, it has been shown to protect proteins from oxidation by a similar mechanism [30], and to prevent oxidative DNA damage such as strand breakages [8,31]. As well as its role in membranes, CoQ is also believed to function in the blood to protect lipoproteins such as very low density (VLDL), low density (LDL) and high density (HDL) lipoproteins from oxidation [8]. The oxidised quinone product is rapidly and efficiently reduced to the quinol by enzyme systems in both the blood and the tissues, thus maintaining a high level of the active form [8].

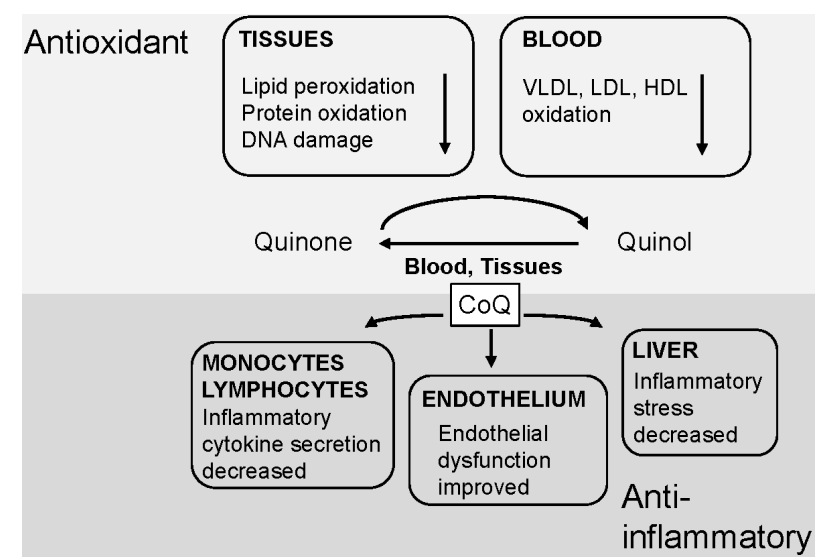

Figure 2. Antioxidant and anti-inflammatory functions of CoQ. Lipids, proteins and DNA and lipoproteins in the blood are protected from oxidative damage by the conversion of the quinone form of CoQ to the quinol form. The quinol is rapidly reconverted to the quinone in both blood and tissues. CoQ has also been shown to decrease cytokine secretion in monocytes and lymphocytes, to improve endothelial function and to reduce hepatic inflammatory stress.

As well as acting as an efficient antioxidant, current evidence suggests that CoQ has a number of independent anti-inflammatory effects [31,32]. It has been shown to reduce the secretion of pro-inflammatory cytokines in monocytes and lymphocytes after an inflammatory stimulus via an influence on the expression of NF-KB-dependent genes [14,24,33,34]. Furthermore, dietary 
supplementation with $\mathrm{CoQ}_{10}$ has been reported to improve endothelial dysfunction in patients with diabetes by up-regulating nitric oxide production (patients received $200 \mathrm{mg} \mathrm{CoQ} 10 /$ day for 12 weeks) $[24,35,36]$, and to decrease the hepatic inflammatory stress caused by obesity in mice (see below) [14].

CoQ therapy has an obvious application in mitochondrial disease [28,37], but its antioxidant and anti-inflammatory effects have led to considerable interest in its possible beneficial effects in other chronic diseases, in particular cardiovascular disease [38,39], but also in neurodegenerative disorders including Parkinson's disease, Huntington's disease and Freidreich's ataxia [38,40-42]. It has also been reported to reduce the risk of pre-eclampsia in pregnancy and to increase sperm quality in infertile men $[38,43,44]$. The list of conditions influenced by CoQ continues to grow, and below we present evidence from recent studies that suggests that changes in its metabolism may also have a role in NAFLD development and progression. The antioxidant and anti-inflammatory functions of CoQ are summarised in Figure 2.

\section{Pathogenesis of NAFLD Development and Progression}

NAFLD is defined as the presence of abnormal fat deposition in the liver (steatosis) without inflammation in individuals who do not consume excessive amounts of alcohol, and its occurrence is strongly associated with metabolic disorders such as obesity, diabetes and the metabolic syndrome [1,2]. The simple steatosis may progress to non-alcoholic steatohepatitis (NASH) (about $25 \%$ of cases), in which the fat accumulation is accompanied by inflammation and hepatocyte ballooning. Approximately $20 \%$ of NASH patients will develop fibrosis and cirrhosis, and in $1 \%$ of cases per year cirrhosis progresses to liver carcinoma [2]. The hepatic diseases and main clinical conditions involved in NAFLD development are well known and described in terms diagnostic criteria [45], and, although the pathogenesis from healthy liver to the disease condition remains incompletely understood, oxidative stress and insulin resistance have been strongly implicated as causative factors $[5,46]$.

The finding that the risk of progression of NAFLD to NASH is related to the severity of fat deposition led Day et al. [47] to propose the "two hit" hypothesis in 1998. The first hit is the simple hepatic steatosis which results from the development of insulin resistance, and this leads to conditions in which the liver becomes more sensitive to the second hits which include oxidative stress, mitochondrial dysfunction and inflammation [2,4,47]. More recently, however, it has become clear that polymorphism in the gene for patatin-like phospholipase 3 (PNPLA3) also plays a role in NASH development, thus it is more accurately described as a multiple hit process [4].

In the normal liver, there is a balance between the synthesis and esterification of fatty acids (FFA) which increases hepatic TAG content, and VLDL secretion and fatty acid oxidation which decreases it [48]. In insulin resistance, however, there is an increased supply of fatty acids to hepatocytes, causing not only fat accumulation but also a rise in mitochondrial $\beta$-oxidation, and consequently increased oxidative stress caused by raised levels of reactive oxygen species (ROS), lipid peroxidation, protein oxidation and the production of pro-inflammatory cytokines $[5,49]$. Recent studies have also suggested that oxidative stress may be a primary cause of liver fat accumulation [50], and ROS have also been shown to play a part in fibrosis development [51]. In addition, blood antioxidant concentrations have been reported to be decreased in patients with NAFLD [52]. It is now clear, therefore, that oxidative stress is a major factor in the development of NAFLD and its progression to NASH. Furthermore, a large proportion of cellular ROS are produced in mitochondria, and overproduction of ROS when mitochondrial respiration is disrupted has been suggested to be important in NAFLD development [53-55]. The presence of mitochondrial dysfunction in patients with NASH also indicates that it is likely to have important role in the pathogenesis of the disease $[56,57]$. Figure 3 summarises current ideas on the pathogenesis of NAFLD development and progression. 


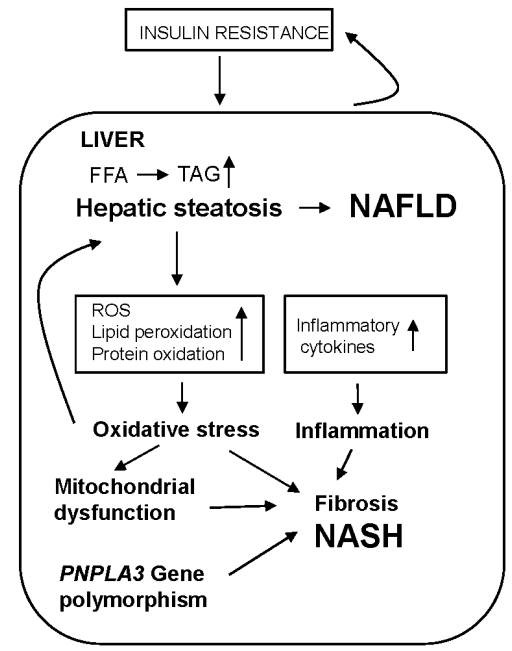

Figure 3. The development and progression of NAFLD. The development of insulin resistance increases the supply of free fatty acids (FFA) to the liver causing increased TAG synthesis and hepatic steatosis. Oxidative stress may also contribute to this process. The steatosis leads to inflammation and increased oxidative stress, which in turn causes mitochondrial dysfunction. These conditions, together with other factors such as PNPLA3 gene polymorphism, result in the development of fibrosis and ultimately NASH. In the traditional 2 hit hypothesis [48] the initial steatosis is the first hit and the second hits are the resulting oxidative stress and inflammation. It is now clear, however, that multiple hits are involved in the process.

\section{CoQ and NAFLD Development and Progression}

Both the role of $\mathrm{CoQ}$ in mitochondria and its function as an efficient endogenously synthesised antioxidant $[8,10,21]$ suggest that it may play a part in the development of NAFLD and its progression to NASH, and evidence for this has begun to emerge from recent investigations. In general, two main approaches have been used. The first has been to study the relationship between the disease and CoQ metabolism in the body and the second to assess the influence of dietary supplementation with CoQ on the development of the condition. So far, the majority of studies have used animal models of NAFLD or $\mathrm{NASH}$, mainly in rats and mice, but as interest grows, more human studies are being undertaken.

Studies to date on how CoQ metabolism is changed in NAFLD have given conflicting results. As early as 1996, Eaton et al. [18] suggested from their work on $\beta$-oxidation in patients with alcoholic and non-alcoholic liver disease that decreased amounts of CoQ may contribute to hepatic steatosis in NASH , and more recently, Yesilova et al. [19] found that $\mathrm{CoQ}_{10}$ levels were depleted in men with NAFLD in comparison with normal subjects. Moreover, these authors also showed that there was a negative correlation between $\mathrm{CoQ}_{10}$ and body fat and also inflammatory activity and fibrosis [19]. In an investigation with obese rats, exposure of the animals to a mixture of environmental contaminants implicated in NAFLD development and progression has been reported to cause a decrease in liver $\mathrm{CoQ}_{10}$ concentrations [57], and the activity of geranylgeranyl pyrophosphate synthase, an enzyme involved in the formation of isoprene units, was also decreased in these conditions. The authors conclude from this that de novo synthesis of CoQ is depressed in NAFLD, but measurement of levels of $\mathrm{CoQ}_{9}$, the main endogenous form in rats, would be required to confirm this. In contrast, Bravo et al. [20] found that plasma levels of $\mathrm{CoQ}_{9}$ were increased in rats with high fat diet-induced NAFLD, while concentrations of $\mathrm{CoQ}_{10}$, which is likely to be mainly derived from exogenous sources, were not significantly changed. Furthermore, there was an increase of about $75 \%$ in the proportion of total plasma CoQ $\left(\mathrm{CoQ}_{9}+\mathrm{CoQ}_{10}\right)$ in the reduced form. Another study using a mouse model of NASH found increased levels of plasma $\mathrm{CoQ}_{9}$ in the animals, and the rise was positively correlated with hepatic ROS concentrations, hypercholesterolemia and fibrosis [58]. Since increases were observed in $\mathrm{CoQ}_{9}$, but not $\mathrm{CoQ}_{10}$ in these experiments [20,58], it seems likely that this change reflects 
up-regulation of endogenous synthesis which may be an protective response against a general reduction in the antioxidant capacity of the plasma which occurs in NAFLD [15,52]. In addition, respiratory activity and the activity of liver mitochondrial NADH-CoQ oxidoreductase (complex I of the respiratory chain) have been shown to be decreased in rats with NAFLD induced by choline deficiency [9]. Current evidence, therefore, clearly indicates that CoQ metabolism is disturbed in NAFLD, but further studies are required to elucidate how exactly this relates to the development and progression of the disease.

The finding that changes in CoQ metabolism are potentially involved in the development and progression of NAFLD raises the question of whether dietary supplementation with the quinone may be beneficial in the prevention or treatment of the condition. Although only a few studies have investigated the direct effects of CoQ supplementation on NAFLD (see below), a number of investigations in both humans and animals have provided evidence in areas known to be associated with the disease such as oxidative stress and mitochondrial dysfunction (studies on dietary supplementation with CoQ are summarised in Table 1). Despite the fact that $\mathrm{CoQ}_{9}$ is the endogenous form in rats and mice, with just a few exceptions (see below), investigations with animals have used $\mathrm{CoQ}_{10}$ as the dietary supplement.

Dietary supplementation with $\mathrm{CoQ}_{10}(300 \mathrm{mg} /$ day for 12 days $)$ has been found to reduce serum markers of oxidative stress in young swimmers [59] and, in a series of studies in patients with coronary artery disease (60-300 mg CoQ ${ }_{10} /$ day for 12 weeks), to reduce oxidative stress and increase the activity of antioxidant enzymes as well as lowering inflammation as assessed by plasma levels of inflammatory markers such as tumour necrosis factor (TNF)- $\alpha$ and interleukin (IL)-6 [12,13,60,61]. Similarly, dietary CoQ (diet supplemented with $0.07 \%-0.7 \%(w / w) C_{0} Q_{10}$ for 26 weeks) was associated with a reduction in plasma oxidative stress and inflammatory markers in a rat model of the metabolic syndrome [62]. In healthy sedentary men given oral $\mathrm{CoQ}_{10}(100 \mathrm{mg} /$ day for 8 weeks), however, Gobkel et al. [11] reported that blood levels of TNF- $\alpha$ and interleukin (IL)-6 were unchanged over the 8 week experimental period.

In the liver in general, animal studies have shown that dietary $\operatorname{CoQ}_{10}$ is hepatoprotective against toxic agents including acetaminophen (rats were given a single oral dose of acetaminophen $(700 \mathrm{mg} / \mathrm{kg}$ ), two injections (i.p.) of $\mathrm{CoQ}_{10}$ at 1 and $12 \mathrm{~h}$ and killed at $24 \mathrm{~h}$ ) and carbon tetrachloride (a single i.p. dose of $200 \mathrm{mg} / \mathrm{kg} \mathrm{CoQ} 10$ was administered $24 \mathrm{~h}$ before injection of CCl4 $(1 \mathrm{~mL} / \mathrm{kg})$ s.c. and animals were killed $24 \mathrm{~h}$ later) in rats [63,64], inhibits liver fibrosis induced by dimethylnitrosamine $(\mathrm{DMN})$ (10 or $30 \mathrm{mg} \mathrm{CoQ}_{10}$ given orally before administration of $\mathrm{mDMN}$ and 3 times/week thereafter for 3 weeks) or eggs of the parasitic worm Schistoma mansoni (S. mansoni) (oral dose of $5 \mathrm{mg} / \mathrm{kg} \mathrm{CoQ}{ }_{10}$ daily for 8 or 12 weeks after infection) in mice [65,66], and limits ischemic damage in transplanted livers when the donor rat is pretreated $(10 \mathrm{mg} / \mathrm{kg}$ CoQ 10 given i.v. $1 \mathrm{~h}$ before induction of ischemia) [67]. Intraperitoneal administration of $\mathrm{CoQ}_{10}$ (8 mg i.p. every second day for 38 days) has been shown to lower liver TAG content in rats [68], suggesting that it could be protective against hepatic fat deposition in NAFLD. Hepatic oxidative stress and inflammation has also been found to be reduced by $\mathrm{CoQ}_{10}$ therapy in several animal studies. In a model of diet-induced obesity, a high risk condition for NAFLD development in mice, Sohet et al. [14] showed that the expression of mRNA for a panel of hepatic genes involved in ROS production, inflammation and metabolic stress was reduced in the animals fed $\mathrm{CoQ}$ (diet supplemented with $1 \% \mathrm{CoQ}_{10}$ for 60 days), and Othman et al. [66], also found that the quinone decreased oxidative stress and preserved antioxidant factors in livers of mice infected with S. mansoni (study details given above). In contrast, in another study although both $C_{0} Q_{9}$ and $C_{0} Q_{10}$ levels in the liver were increased in rats fed a diet supplemented with $C_{0} Q_{10}$ $(62 \mathrm{mg} / \mathrm{kg}$ ) for 6 or 12 months, the activities of the hepatic antioxidant enzymes measured were either unchanged or decreased [69]. Hepatic mitochondrial dysfunction has also been shown to be improved by $\mathrm{CoQ}_{10}(0.57 \mathrm{mg} /$ day for 6 weeks) in rats given a high cholesterol diet and atorvastatin [70] and in cultured human hepatocytes treated with D-galactosamine, an inducer of oxidative stress and cell death and $30 \mu \mathrm{M}$ CoQ [71]. 
Table 1. Summary of studies on the effects of dietary CoQ supplementation on NAFLD and related factors.

\begin{tabular}{|c|c|c|c|c|}
\hline Subjects/Animals/Cells & Oxidative Stress (OS) & Inflammation & Other & References \\
\hline Young swimmers & $\begin{array}{l}\text { Plasma OS markers MDA, NO, } \\
\text { protein hydroperoxide decreased; } \\
\text { total antioxidant capacity increased }\end{array}$ & & & [59] \\
\hline $\begin{array}{l}\text { Patients with coronary artery } \\
\text { disease }\end{array}$ & $\begin{array}{l}\text { Plasma MDA reduced; SOD, CAT, } \\
\text { GPx activites increased }\end{array}$ & Plasma TNF- $\alpha$, IL-6 reduced & & {$[12,13,60,61]$} \\
\hline Rats with the metabolic syndrome & Plasma oxidised LDL decreased & Plasma hsCRP reduced & Endothelial dysfunction improved & [62] \\
\hline Healthy sedentary men & & $\begin{array}{c}\text { Plasma TNF- } \alpha \text {, IL-6 levels } \\
\text { unchanged }\end{array}$ & & [11] \\
\hline $\begin{array}{l}\text { Rats with liver injury induced by } \\
\text { acetominophen or } \mathrm{CCl}_{4}\end{array}$ & $\begin{array}{l}\text { Liver GSH increased; lipid } \\
\text { peroxides decreased }\end{array}$ & & $\begin{array}{l}\text { Liver tissue damage ameliorated; } \\
\text { liver NF-kB, caspase } 3 \text { and } \\
\text { inducible NO synthase }\end{array}$ & {$[63,64]$} \\
\hline Mice with diet-induced obesity & $\begin{array}{l}\text { Liver expression of NADPH } \\
\text { oxidase decreased }\end{array}$ & $\begin{array}{c}\text { Liver expression of CRP, STAMP2 } \\
\text { decreased }\end{array}$ & $\begin{array}{c}\text { Liver expression of CPT1 } \alpha \\
\text { decreased }\end{array}$ & [14] \\
\hline $\begin{array}{l}\text { Mice with liver fibrosis induced by } \\
\text { DMN or } S \text { mansoni }\end{array}$ & $\begin{array}{l}\text { Liver MDA decreased; GSH } \\
\text { increased }\end{array}$ & $\begin{array}{c}\text { Liver TGF- } \beta \text { reduced, Nrf2/ARE } \\
\text { activated }\end{array}$ & Liver fibrosis decreased & {$[65,66]$} \\
\hline Liver transplantation donor rats & & & $\begin{array}{l}\text { Ischemic damage in transplanted } \\
\text { liver prevented }\end{array}$ & [67] \\
\hline Rats $\left(\mathrm{CoQ}_{10}\right.$ given IP) & & & Lipid content of liver decreased & [68] \\
\hline Rats fed sunflower oil or olive oil & $\begin{array}{l}\text { Liver antioxidant enzyme activities } \\
\text { unchanged or decreased }\end{array}$ & & & [69] \\
\hline $\begin{array}{c}\text { Rats fed a high cholesterol diet and } \\
\text { atorvastatin }\end{array}$ & & & $\begin{array}{l}\text { Serum and liver cholesterol and TG } \\
\text { lowered; mitochondrial respiration } \\
\text { improved }\end{array}$ & [70] \\
\hline Rats with diet-induced NAFLD * & Plasma oxidised $\mathrm{CoQ}_{9}$ increased & & $\begin{array}{c}\text { Liver injury, steatosis, VLDL } \\
\text { production unchanged; microsomal } \\
\text { apoB, TG and membrane } \\
\text { phospholipid increased; plasma } \\
\text { leptin increased }\end{array}$ & {$[15,16]$} \\
\hline $\begin{array}{l}\text { Cultured human hepatocytes } \\
\text { treated with D-galactosamine }\end{array}$ & ROS generation decreased & & $\begin{array}{c}\text { Electron transport chain } \\
\text { dysfunction improved }\end{array}$ & [71] \\
\hline Humans with NAFLD & $\begin{array}{c}\text { Serum total antioxidant capacity } \\
\text { decreased }\end{array}$ & & $\begin{array}{l}\text { Serum AST decreased, waist } \\
\text { circumference decreased }\end{array}$ & [46] \\
\hline Humans with NAFLD & Oxidative stress staus unchanged & & $\begin{array}{l}\text { No beneficial effects on serum lipid } \\
\text { profile or blood pressure }\end{array}$ & [72] \\
\hline
\end{tabular}

GPx: glutathione peroxidase; GSH: reduced glutathione; hsCRP: high sensitivity CRP; MDA: malondialdehyde; SOD; superoxide dismutase; STAMP2. six transmembrane protein of prostate 2. ${ }^{*} \mathrm{CoQ}_{9}$ was used as the dieatry supplement. In all other studies listed $\mathrm{CoQ}_{10}$ was used. 
The studies discussed above suggest that CoQ therapy may be beneficial effect in alleviating some of the causal factors of NAFLD, including oxidative stress, inflammation and mitochondrial dysfunction. Building on this base, our group investigated the direct effects of dietary supplementation with $\mathrm{CoQ}_{9}$ on the development of the disease using a high fat diet- induced model in rats $[15,16] . \mathrm{CoQ}_{9}$ was used rather that $\mathrm{CoQ}_{10}$ as it is the main endogenously synthesised form in the test species [21]. We used a dose of $30 \mathrm{mg} / \mathrm{kg} /$ day $\mathrm{CoQ}_{9}$ for 8 weeks after feeding a high fat diet for 10 weeks. NAFLD was found to be associated with increased, rather than reduced, plasma $\mathrm{CoQ}_{9}$ levels, while $\mathrm{CoQ}_{10}$ (mostly originating from the diet) concentrations were unaffected. However, the ratio of $\mathrm{CoQ}_{9}: \mathrm{CoQ}_{10}$ was significantly higher in NAFLD rats given the dietary supplement and plasma oxidized $\mathrm{CoQ}_{9}$ levels were also raised, effects which may be responses to increased oxidative stress [15]. Dietary $\mathrm{CoQ}_{9}$ was not found to have significant effects on hepatic steatosis, liver injury, the development of insulin resistance or increased production of VLDL seen in NAFLD, although it did cause a rise in plasma leptin levels, an effect which is likely to be detrimental rather than beneficial.

Under normal physiological conditions, the liver produces and secretes VLDL when energy for peripheral tissues is needed. TAG is transferred into the endoplasmic reticulum (ER), where it enters the VLDL precursor pathway [73]. In NAFLD, however, there is overproduction of large, TAG-rich VLDL causing hypertriglyceridemia [74]. Since a number of crucial steps in VLDL synthesis depend on the proper functioning of the ER membrane [73], Cano and colleagues carried out another study to investigate the effects of dietary $\mathrm{CoQ}_{9}$ on hepatic VLDL processing in rats with NAFLD [16]. CoQ, was shown to have a number of effects including increasing microsomal levels of apoB and TAG and changing the microsomal membrane phospholipid content [16]. This kind of membrane change could delay the transfer of the nascent lipoproteins out of the ER into the secretory pathway, triggering increased apoB synthesis and TAG-rich VLDL particle size, and leading to the secretion of larger particles while the total concentration of VLDL TAG remains unchanged. Thus, although dietary $\mathrm{CoQ}_{9}$ was shown to affect VLDL secretion in hepatic steatosis, the changes may not be beneficial as they could lead to the production of larger, more atherogenic VLDL.

In human subjects with NAFLD, oral $\mathrm{CoQ}_{10}(100 \mathrm{mg} /$ day for 4 weeks) has been reported to reduce waist circumference and decrease serum levels of aspartate aminotransferase, but was also found to decrease serum total antioxidant capacity [46], and in a second study (100 mg daily for 12 weeks), no beneficial effects were found [72]. Clearly, in considering dietary supplementation with CoQ as a therapy for NAFLD, it is important to establish whether it is able to bring about a reduction in hepatic fat accumulation and to prevent the development of fibrosis and carcinoma in the longer term. Because of the limited number of studies which have investigated effects on NAFLD directly, however, conclusive evidence is not yet available in these areas. CoQ administration has been reported to decrease hepatic steatosis in rats in one study [68], but in our work using a rat model of NAFLD we found no change [15]; liver fibrosis and hepatocellular carcinoma have been shown to be inhibited in rodents $[65,66,75]$, but in these cases the conditions were induced chemically rather than as a result of NAFLD/NASH. Overall, therefore, studies to date, have not shown any direct benefit of CoQ therapy in combatting NAFLD development, however, as they are so few there is clearly a need for further investigations, and in particular for more human intervention studies, before any definitive conclusions can be reached.

\section{Summary and Conclusions}

Recent research has shown that oxidative stress, mitochondrial dysfunction and inflammation are key factors in the development of NAFLD and its progression to NASH [2,4,47]. The essential role of $\mathrm{CoQ}$ in mitochondria, therefore, together with its function as an efficient, endogenously synthesised antioxidant and its anti-inflammatory properties $[8,10,21,24]$ suggest that disturbances in its metabolism may be involved in the pathogenesis of the disease, and evidence for this is now emerging. Investigations, mainly using animal models so far, have shown that CoQ metabolism is altered as NAFLD progresses, although its exact relationship to the disease process remains 
to be determined. Experiments with both animals and humans have demonstrated that dietary supplementation with CoQ is potentially beneficial for NAFLD, since it reduces oxidative stress and inflammation, improves mitochondrial dysfunction and is generally hepatoprotective. However, only a few studies either in animal models or in patients have assessed the direct effects of dietary CoQ in NAFLD to date, and the results have been inconclusive. Despite this, current evidence clearly indicates that CoQ is likely to be involved in NAFLD development and further studies, particularly with human subjects, are needed both to fully elucidate its role and to resolve the question of the efficacy of CoQ therapy in alleviating the effects of the condition.

Author Contributions: Botham KM performed the literature review and drafted the manuscript; Napolitano M provided editorial support and contributed to the literature review; Bravo E contributed to the conception and design of the review. All of them discussed, revised and approved the manuscript.

Conflicts of Interest: The authors declare no conflict of interest.

\section{References}

1. Adams, L.A.; Angulo, P.; Lindor, K.D. Nonalcoholic fatty liver disease. CMAJ 2005, 172, 899-905. [CrossRef] [PubMed]

2. Than, N.N.; Newsome, P.N. Non-alcoholic fatty liver disease: When to intervene and with what. Clin. Med. 2015, 15, 186-190. [CrossRef] [PubMed]

3. Sumida, Y.; Niki, E.; Naito, Y.; Yoshikawa, T. Involvement of free radicals and oxidative stress in NAFLD/NASH. Free Radic. Res. 2013, 47, 869-880. [CrossRef] [PubMed]

4. Takaki, A.; Kawai, D.; Yamamoto, K. Multiple hits, including oxidative stress, as pathogenesis and treatment target in non-alcoholic steatohepatitis (NASH). Int. J. Mol. Sci. 2013, 14, 20704-20728. [CrossRef] [PubMed]

5. Videla, L.A.; Rodrigo, R.; Araya, J.; Poniachik, J. Insulin resistance and oxidative stress interdependency in non-alcoholic fatty liver disease. Trends Mol. Med. 2006, 12, 555-558. [CrossRef] [PubMed]

6. Grattagliano, I.; Palmieri, V.O.; Portincasa, P.; Moschetta, A.; Palasciano, G. Oxidative stress-induced risk factors associated with the metabolic syndrome: A unifying hypothesis. J. Nutr. Biochem. 2008, 19, 491-504. [CrossRef] [PubMed]

7. Rolo, A.P.; Teodoro, J.S.; Palmeira, C.M. Role of oxidative stress in the pathogenesis of nonalcoholic steatohepatitis. Free Radic. Biol. Med. 2012, 52, 59-69. [CrossRef] [PubMed]

8. Bentinger, M.; Brismar, K.; Dallner, G. The antioxidant role of coenzyme Q. Mitochondrion 2007, 7 (Suppl.), S41-S50. [CrossRef] [PubMed]

9. Petrosillo, G.; Portincasa, P.; Grattagliano, I.; Casanova, G.; Matera, M.; Ruggiero, F.M.; Ferri, D.; Paradies, G. Mitochondrial dysfunction in rat with nonalcoholic fatty liver Involvement of complex I, reactive oxygen species and cardiolipin. Biochim. Biophys. Acta 2007, 1767, 1260-1267. [CrossRef] [PubMed]

10. Nowicka, B.; Kruk, J. Occurrence, biosynthesis and function of isoprenoid quinones. Biochim. Biophys. Acta 2010, 1797, 1587-1605. [CrossRef] [PubMed]

11. Gökbel, H.; Gergerlioğlu, H.S.; Okudan, N.; Gül, I.; Büyükbaş, S.; Belviranli, M. Effects of coenzyme Q10 supplementation on plasma adiponectin, interleukin-6, and tumor necrosis factor- $\alpha$ levels in men. J. Med. Food 2010, 13, 216-218. [CrossRef] [PubMed]

12. Lee, B.J.; Tseng, Y.F.; Yen, C.H.; Lin, P.T. Effects of coenzyme Q10 supplementation (300 mg/day) on antioxidation and anti-inflammation in coronary artery disease patients during statins therapy: A randomized, placebo-controlled trial. Nutr. J. 2013, 12, 142. [CrossRef] [PubMed]

13. Lee, B.J.; Huang, Y.C.; Chen, S.J.; Lin, P.T. Coenzyme Q10 supplementation reduces oxidative stress and increases antioxidant enzyme activity in patients with coronary artery disease. Nutrition 2012, 28, 250-255. [CrossRef] [PubMed]

14. Sohet, F.M.; Neyrinck, A.M.; Pachikian, B.D.; de Backer, F.C.; Bindels, L.B.; Niklowitz, P.; Menke, T.; Cani, P.D.; Delzenne, N.M. Coenzyme Q10 supplementation lowers hepatic oxidative stress and inflammation associated with diet-induced obesity in mice. Biochem. Pharmacol. 2009, 78, 1391-1400. [CrossRef] [PubMed] 
15. Safwat, G.M.; Pisanò, S.; D’Amore, E.; Borioni, G.; Napolitano, M.; Kamal, A.A.; Ballanti, P.; Botham, K.M.; Bravo, E. Induction of non-alcoholic fatty liver disease and insulin resistance by feeding a high-fat diet in rats: Does coenzyme Q monomethyl ether have a modulatory effect? Nutrition 2009, 25, 1157-1168. [CrossRef] [PubMed]

16. Cano, A.; Ciaffoni, F.; Safwat, G.M.; Aspichueta, P.; Ochoa, B.; Bravo, E.; Botham, K.M. Hepatic VLDL assembly is disturbed in a rat model of nonalcoholic fatty liver disease: Is there a role for dietary coenzyme Q? J. Appl. Physiol. 2009, 107, 707-717. [CrossRef] [PubMed]

17. Huertas, J.R.; Battino, M.; Lenaz, G.; Mataix, F.J. Changes in mitochondrial and microsomal rat liver coenzyme Q9 and Q10 content induced by dietary fat and endogenous lipid peroxidation. FEBS Lett. 1991, 287, 89-92. [CrossRef]

18. Eaton, S.; Zaitoun, A.M.; Record, C.O.; Bartlett, K. beta-Oxidation in human alcoholic and non-alcoholic hepatic steatosis. Clin. Sci. (Lond.) 1996, 90, 307-313. [CrossRef] [PubMed]

19. Yesilova, Z.; Yaman, H.; Oktenli, C.; Ozcan, A.; Uygun, A.; Cakir, E.; Sanisoglu, S.Y.; Erdil, A.; Ates, Y.; Aslan, M.; et al. Systemic markers of lipid peroxidation and antioxidants in patients with nonalcoholic Fatty liver disease. Am. J. Gastroenterol. 2005, 100, 850-855. [CrossRef] [PubMed]

20. Bravo, E.; Palleschi, S.; Rossi, B.; Napolitano, M.; Tiano, L.; D’Amore, E.; Botham, K.M. Coenzyme Q metabolism is disturbed in high fat diet-induced non-alcoholic fatty liver disease in rats. Int. J. Mol. Sci. 2012, 13, 1644-1657. [CrossRef] [PubMed]

21. Laredj, L.N.; Licitra, F.; Puccio, H.M. The molecular genetics of coenzyme $Q$ biosynthesis in health and disease. Biochimie 2014, 100, 78-87. [CrossRef] [PubMed]

22. Wang, Y.; Hekimi, S. Molecular genetics of ubiquinone biosynthesis in animals. Crit. Rev. Biochem. Mol. Biol. 2013, 48, 69-88. [CrossRef] [PubMed]

23. Turunen, M.; Olsson, J.; Dallner, G. Metabolism and function of coenzyme Q. Biochim. Biophys. Acta 2004, 1660, 171-199. [CrossRef] [PubMed]

24. Bentinger, M.; Tekle, M.; Dallner, G. Coenzyme Q-biosynthesis and functions. Biochem. Biophys. Res. Commun. 2010, 396, 74-79. [CrossRef] [PubMed]

25. Quinzii, C.M.; Hirano, M. Primary and secondary CoQ(10) deficiencies in humans. Biofactors 2011, 37, 361-365. [CrossRef] [PubMed]

26. Goldstein, J.L.; Brown, M.S. Regulation of the mevalonate pathway. Nature 1990, 343, 425-430. [CrossRef] [PubMed]

27. Potgieter, M.; Pretorius, E.; Pepper, M.S. Primary and secondary coenzyme Q10 deficiency: The role of therapeutic supplementation. Nutr. Rev. 2013, 71, 180-188. [CrossRef] [PubMed]

28. Hargreaves, I.P. Coenzyme Q10 as a therapy for mitochondrial disease. Int. J. Biochem. Cell. Biol. 2014, 49, 105-111. [CrossRef] [PubMed]

29. Hoffman, C.H.; Trenner, N.R.; Arison, B.H.; Shunk, C.H.; Linn, B.O.; McPherson, J.F.; Folkers, K. Coenzyme Q. I. Structure studies on the coenzyme Q group. J. Am. Chem. Soc. 1958, 80, 4750-4752. [CrossRef]

30. Forsmark-Andrée, P.; Dallner, G.; Ernster, L. Endogenous ubiquinol prevents protein modification accompanying lipid peroxidation in beef heart submitochondrial particles. Free Radic. Biol. Med. 1995, 19, 749-757. [CrossRef]

31. Ernster, L.; Dallner, G. Biochemical, physiological and medical aspects of ubiquinone function. Biochim. Biophys. Acta 1995, 1271, 195-204. [CrossRef]

32. Schmelzer, C.; Lorenz, G.; Rimbach, G.; Döring, F. Influence of Coenzyme Q_\{10\} on release of pro-inflammatory chemokines in the human monocytic cell line THP-1. Biofactors 2007, 31, 211-217. [CrossRef] [PubMed]

33. Schmelzer, C.; Lorenz, G.; Rimbach, G.; Döring, F. In Vitro Effects of the Reduced Form of Coenzyme Q(10) on Secretion Levels of TNF- $\alpha$ and Chemokines in Response to LPS in the Human Monocytic Cell Line THP-1. J. Clin. Biochem. Nutr. 2009, 44, 62-66. [CrossRef] [PubMed]

34. Mohseni, M.; Vafa, M.R.; Hajimiresmail, S.J.; Zarrati, M.; Rahimi Forushani, A.; Bitarafan, V.; Shidfar, F. Effects of coenzyme Q10 supplementation on serum lipoproteins, plasma fibrinogen, and blood pressure in patients with hyperlipidemia and myocardial infarction. Iran. Red Crescent Med. J. 2014, 16, e16433. [CrossRef] [PubMed] 
35. Hamilton, S.J.; Chew, G.T.; Watts, G.F. Therapeutic regulation of endothelial dysfunction in type 2 diabetes mellitus. Diab. Vasc. Dis. Res. 2007, 4, 89-102. [CrossRef] [PubMed]

36. Watts, G.F.; Playford, D.A.; Croft, K.D.; Ward, N.C.; Mori, T.A.; Burke, V. Coenzyme Q(10) improves endothelial dysfunction of the brachial artery in Type II diabetes mellitus. Diabetologia 2002, 45, 420-426. [CrossRef] [PubMed]

37. Quinzii, C.M.; Hirano, M. Coenzyme Q and mitochondrial disease. Dev. Disabil. Res. Rev. 2010, 16, $183-188$. [CrossRef] [PubMed]

38. Littaru, G.P.; Tiano, L. Clinical aspects of coenzyme Q10: An update. Nutrition 2010, 26, 250-254. [CrossRef] [PubMed]

39. Littarru, G.P.; Tiano, L.; Belardinelli, R.; Watts, G.F. Biochemical rationale and experimental data on the antiaging properties of $\mathrm{CoQ}(10)$ at skin level. Biofactors 2011, 7, 381-385. [CrossRef]

40. Henchcliffe, C.; Beal, M.F. Mitochondrial biology and oxidative stress in Parkinson disease pathogenesis. Nat. Clin. Pract. Neurol. 2008, 4, 600-609. [CrossRef] [PubMed]

41. Cooper, J.M.; Schapira, A.H. Friedreich's ataxia: Coenzyme Q10 and vitamin E therapy. Mitochondrion 2007, 7 (Suppl.), S127-S135. [CrossRef] [PubMed]

42. Huntington Study Group Pre2CARE. Investigators. Safety and tolerability of high-dosage coenzyme Q10 in Huntington's disease and healthy subjects. Mov. Disord. 2010, 25, 1924-1928. [CrossRef]

43. Teran, E.; Hernandez, I.; Nieto, B.; Tavara, R.; Ocampo, J.E.; Calle, A. Coenzyme Q10 supplementation during pregnancy reduces the risk of pre-eclampsia. Int. J. Gynaecol. Obstet. 2009, 105, 43-45. [CrossRef] [PubMed]

44. Balercia, G.; Buldreghini, E.; Vignini, A.; Tiano, L.; Paggi, F.; Amoroso, S.; Ricciardo-Lamonica, G.; Boscaro, M.; Lenzi, A.; Littarru, G. Coenzyme Q10 treatment in infertile men with idiopathic asthenozoospermia: A placebo-controlled, double-blind randomized trial. Fertil. Steril. 2009, 91, 1785-1792. [CrossRef] [PubMed]

45. Santos, J.C.; Valentim, I.B.; de Araújo, O.R.; Ataide, T.R.; Goulart, M.O. Development of nonalcoholic hepatopathy: Contributions of oxidative stress and advanced glycation end products. Int. J. Mol. Sci. 2013, 14, 19846-19866. [CrossRef] [PubMed]

46. Farhangi, M.A.; Alipour, B.; Jafarvand, E.; Khoshbaten, M. Oral coenzyme $\mathrm{Q}_{10}$ supplementation in patients with nonalcoholic fatty liver disease: Effects on serum vaspin, chemerin, pentraxin 3, insulin resistance and oxidative stress. Arch. Med. Res. 2014, 45, 589-595. [CrossRef]

47. Day, C.P.; James, O.F.W. Steatohepatitis: A tale of two "hits"? Gastroenterology 1998, 114, 842-845. [CrossRef]

48. Nguyen, P.; Leray, V.; Diez, M.; Serisier, S.; le Bloc'h, J.; Siliart, B.; Dumon, H. Liver lipid metabolism. J. Anim. Physiol. Anim. Nutr. (Berl.) 2008, 92, 272-283. [CrossRef] [PubMed]

49. Day, C.P. Non-alcoholic fatty liver disease: Current concepts and management strategies. Clin. Med. 2006, 6, 19-25. [CrossRef] [PubMed]

50. Pessayre, D.J. Role of mitochondria in non-alcoholic fatty liver disease. J. Gastroenterol. Hepatol. 2007, 22 (Suppl. 1), S20-S27. [CrossRef] [PubMed]

51. Novo, E.; Busletta, C.; Bonzo, L.V.; Povero, D.; Paternostro, C.; Mareschi, K.; Ferrero, I.; David, E.; Bertolani, C.; Caligiuri, A.; et al. Intracellular reactive oxygen species are required for directional migration of resident and bone marrow-derived hepatic pro-fibrogenic cells. J. Hepatol. 2011, 54, 964-974. [CrossRef] [PubMed]

52. Singal, A.K.; Jampana, S.C.; Weinman, S.A. Antioxidants as therapeutic agents for liver disease. Liver Int. 2011, 31, 1432-1448. [CrossRef] [PubMed]

53. Kohli, R.; Pan, X.; Malladi, P.; Wainwright, M.S.; Whitington, P.F. Mitochondrial reactive oxygen species signal hepatocyte steatosis by regulating the phosphatidylinositol 3-kinase cell survival pathway. J. Biol. Chem. 2007, 282, 21327-21336. [CrossRef] [PubMed]

54. Serviddio, G.; Bellanti, F.; Vendemiale, G.; Altomare, E. Mitochondrial dysfunction in nonalcoholic steatohepatitis. Expert Rev. Gastroenterol. Hepatol. 2011, 5, 233-244. [CrossRef] [PubMed]

55. Tessari, P.; Coracina, A.; Cosma, A.; Tiengo, A. Hepatic lipid metabolism and non-alcoholic fatty liver disease. Nutr. Metab. Cardiovasc. Dis. 2009, 19, 291-302. [CrossRef] [PubMed]

56. Nassir, F.; Ibdah, J.A. Role of mitochondria in nonalcoholic fatty liver disease. Int. J. Mol. Sci. 2014, 15, 8713-8742. [CrossRef] [PubMed] 
57. Mailloux, R.J.; Florian, M.; Chen, Q.; Yan, J.; Petrov, I.; Coughlan, M.C.; Laziyan, M.; Caldwell, D.; Lalande, M.; Patry, D.; et al. Exposure to a northern contaminant mixture (NCM) alters hepatic energy and lipid metabolism exacerbating hepatic steatosis in obese JCR rats. PLoS ONE 2014, 9, e106832. [CrossRef] [PubMed]

58. Kohli, R.; Kirby, M.; Xanthakos, S.A.; Softic, S.; Feldstein, A.E.; Saxena, V.; Tang, P.H.; Miles, L.; Miles, M.V.; Balistreri, W.F.; et al. High-fructose, medium chain trans fat diet induces liver fibrosis and elevates plasma coenzyme Q9 in a novel murine model of obesity and nonalcoholic steatohepatitis. Hepatology 2010, 52, 934-944. [CrossRef] [PubMed]

59. Leelarungrayub, D.; Sawttikanon, N.; Klaphajone, J.; Pothongsunan, P.; Bloomer, R.J. Coenzyme Q10 supplementation decreases oxidative stress and improves physical performance in young swimmers: A pilot study. Open Sports Med. J. 2010, 4, 1-8. [CrossRef]

60. Lee, B.J.; Huang, Y.C.; Chen, S.J.; Lin, P.T. Effects of coenzyme Q10 supplementation on inflammatory markers (high-sensitivity C-reactive protein, interleukin-6, and homocysteine) in patients with coronary artery disease. Nutrition 2012, 28, 767-772. [CrossRef] [PubMed]

61. Lee, B.J.; Lin, Y.C.; Huang, Y.C.; Ko, Y.W.; Hsia, S.; Lin, P.T. The relationship between coenzyme Q10, oxidative stress, and antioxidant enzymes activities and coronary artery disease. ScientificWorldJournal 2012, 2012, 792756. [CrossRef] [PubMed]

62. Kunitomo, M.; Yamaguchi, Y.; Kagota, S.; Otsubo, K. Beneficial effect of coenzyme Q10 on increased oxidative and nitrative stress and inflammation and individual metabolic components developing in a rat model of metabolic syndrome. J. Pharmacol. Sci. 2008, 107, 128-137. [CrossRef] [PubMed]

63. Fouad, A.A.; Jresat, I. Hepatoprotective effect of coenzyme Q10 in rats with acetaminophen toxicity. Environ. Toxicol. Pharmacol. 2012, 33, 158-167. [CrossRef] [PubMed]

64. Ali, S.A.; Faddah, L.; Abdel-Baky, A.; Bayoumi, A. Protective effect of L-carnitine and coenzyme Q10 on $\mathrm{CCl}_{4}$-induced liver injury in rats. Sci. Pharm. 2010, 78, 881-896. [CrossRef] [PubMed]

65. Choi, H.K.; Pokharel, Y.R.; Lim, S.C.; Han, H.K.; Ryu, C.S.; Kim, S.K.; Kwak, M.K.; Kang, K.W. Inhibition of liver fibrosis by solubilized coenzyme Q10: Role of Nrf2 activation in inhibiting transforming growth factor-beta1 expression. Toxicol. Appl. Pharmacol. 2009, 240, 377-384. [CrossRef] [PubMed]

66. Othman, A.A.; Shoheib, Z.S.; Abdel-Aleem, G.A.; Shareef, M.M. Experimental schistosomal hepatitis: Protective effect of coenzyme-Q10 against the state of oxidative stress. Exp. Parasitol. 2008, 120, 147-155. [CrossRef] [PubMed]

67. Sumimoto, K.; Inagaki, K.; Ito, H.; Marubayashi, S.; Yamada, K.; Kawasaki, T.; Dohi, K. Ischemic damage prevention by coenzyme Q10 treatment of the donor before orthotopic liver transplantation: Biochemical and histologic findings. Surgery 1987, 102, 821-827. [PubMed]

68. Celik, S.; Akarçay, H.; Yilmaz, O.; Ozkaya, A. Effects of intraperitoneally administered ubiquinone on the level of total lipid and fatty acids in rat liver. Cell Biochem. Funct. 2006, 24, 561-564. [CrossRef] [PubMed]

69. Gómez-Díaz, C.; Burón, M.I.; Alcaín, F.J.; González-Ojeda, R.; González-Reyes, J.A.; Bello, R.I.; Herman, M.D.; Navas, P.; Villalba, J.M. Effect of dietary coenzyme Q and fatty acids on the antioxidant status of rat tissues. Protoplasma 2003, 221, 11-17. [CrossRef] [PubMed]

70. Jiménez-Santos, M.A.; Juárez-Rojop, I.E.; Tovilla-Zárate, C.A.; Espinosa-García, M.T.; Juárez-Oropeza, M.A.; Ramón-Frías, T.; Bermúdez-Ocaña, D.Y.; Díaz-Zagoya, J.C. Coenzyme Q10 supplementation improves metabolic parameters, liver function and mitochondrial respiration in rats with high doses of atorvastatin and a cholesterol-rich diet. Lipids Health Dis. 2014, 13, 22. [CrossRef] [PubMed]

71. González, R.; Ferrín, G.; Hidalgo, A.B.; Ranchal, I.; López-Cillero, P.; Santos-Gónzalez, M.; López-Lluch, G.; Briceño, J.; Gómez, M.A.; Poyato, A.; et al. N-acetylcysteine, coenzyme Q10 and superoxide dismutase mimetic prevent mitochondrial cell dysfunction and cell death induced by D-galactosamine in primary culture of human hepatocytes. Chem. Biol. Interact. 2009, 181, 95-106. [CrossRef] [PubMed]

72. Mohammadshahi, M.; Farsi, F.; Alavi Nejad, P.; Hajiani, E.; Zarei, M.; Ahmadi, K. The Coenzyme Q10 Supplementation Effects on Lipid Profile, Fasting Blood Sugar, Blood Pressure and Oxidative StressStatus among Non-Alcoholic Fatty Liver Disease Patients: A Randomized, Placebo-Controlled, Pilot Study. J. Gastroenterol. Hepatol. Res. 2014, 3, 1108-1113. [CrossRef] 
73. Gibbons, G.F.; Wiggins, D.; Brown, A.M.; Hebbachi, A.M. Synthesis and function of hepatic very-low-density lipoprotein. Biochem. Soc. Trans. 2004, 32, 59-64. [CrossRef] [PubMed]

74. Watts, G.F.; Gan, S.K. Nutrition and metabolism: Non-alcoholic fatty liver disease-pathogenesis, cardiovascular risk and therapy. Curr. Opin. Lipidol. 2008, 19, 92-94. [CrossRef] [PubMed]

75. Fouad, A.A.; al-Mulhim, A.S.; Jresat, I. Therapeutic effect of coenzyme Q10 against experimentally-induced hepatocellular carcinoma in rats. Environ. Toxicol. Pharmacol. 2013, 35, 100-108. [CrossRef] [PubMed]

(C) 2015 by the authors; licensee MDPI, Basel, Switzerland. This article is an open access article distributed under the terms and conditions of the Creative Commons by Attribution (CC-BY) license (http:/ / creativecommons.org/licenses/by/4.0/). 